\title{
REPRODUCTION OF ELEPHANT, LOXODONTA AFRICANA, IN THE LUANGWA VALLEY, ZAMBIA
}

\author{
J. HANKS* \\ National Council for Scientific Research, \\ P.O. Box 49, Chilanga, Zambia
}

(Received 6th May 1971, accepted 23rd July 1971)

Summary. Aspects of reproduction in the African elephant in the Luangwa Valley in Zambia were studied in relation to the population dynamics of the species. The fetal and the secondary sex ratio up to 16 years of age did not depart significantly from equality. Males left family units soon after 16 years of age and joined bachelor herds. From 1964 to $1968,88 \%$ of conceptions were in the rains, but in 1969 there was a shift in the breeding season peak to the dry months of the year. There was no evidence of seasonal breeding in the male elephant. Females reached maturity at 14 years, and males at 15 years, when the combined weights of the testes reached 650 to $700 \mathrm{~g}$, and the mean seminiferous tubule diameter reached 90 to $120 \mu \mathrm{m}$. The mean calving interval was 3.5 to 4.0 years. In the population, $6 \%$ of the elephant were less than 1 year old. Apparent cycles of recruitment were considered to be artefacts caused by slight inaccuracies of the ageing technique used. Corpora albicantia accumulated at the approximate mean rate of $0.6 /$ year, and the significance of this was examined in relation to comparative studies of population fertility. Reproductive senescence was a consequence of a combination of uterine defects and a reduction of oocyte number.

\section{INTRODUCTION}

The Luangwa Valley catchment is situated in parts of the Northern, Eastern and Central Provinces of Zambia, and covers about $40,000 \mathrm{~km}^{2}$ of the country (Text-fig. 1). Elephant, Loxodonta africana Blumenbach, can still be found throughout the Valley away from the settled areas (Ansell, 1960), but are concentrated in the Reserves and Controlled Hunting Areas.

In the mid-Valley region lies the Luangwa Valley South Game Reserve which covers about $7000 \mathrm{~km}^{2}$. Astle, Webster \& Lawrence (1969) have described the geology, soil and vegetation of the South Reserve and, to date, the majority of the research effort in the Luangwa catchment area has been centred in this part of the Valley.

There is one pronounced wet season, rain being confined almost entirely to the period November to March. The mean annual rainfall at Mfuwe (Text-fig. 1) is about $800 \mathrm{~mm}$. The hottest month of the year is just before the

* Present address: Department of Zoology, University College of Rhodesia, P.O. Box MP. 167, Mount Pleasant, Salisbury, Rhodesia. 
start of the rains (October) with a mean daily maximum of $36^{\circ} \mathrm{C}$ and the coolest month is June with a mean daily maximum of $27^{\circ} \mathrm{C}$.

In 1947 (Department of Game and Tsetse Control Annual Report), concern

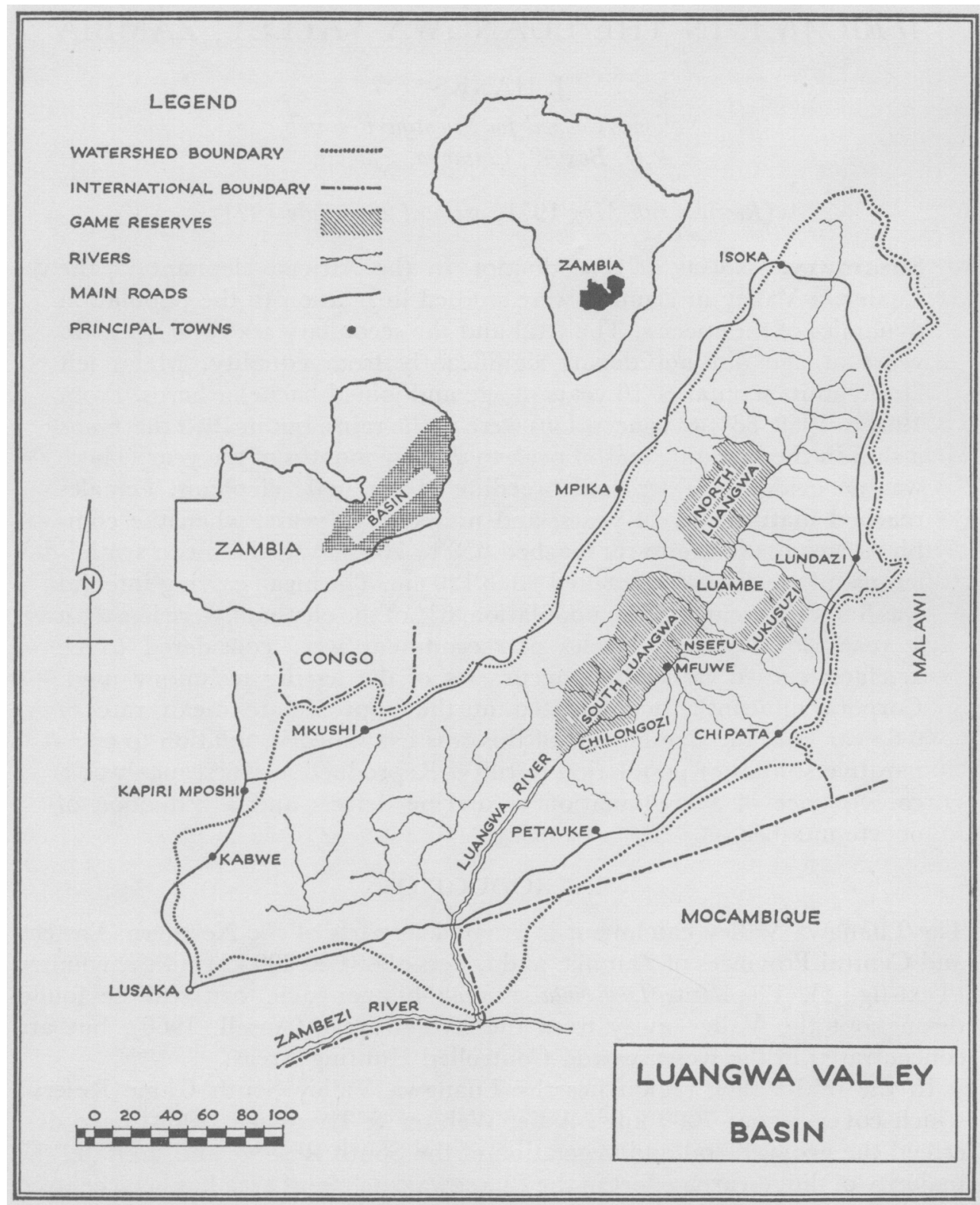

Text-Fig. 1. The Luangwa Valley Basin, showing the position of the South Luangwa Game Reserve.

was expressed for the first time about an apparent increase in elephant, buffalo, Syncerus caffer Sparrman, and hippopotamus, Hippopotamus amphibius Linn., in parts of the Valley and the consequent damage to the vegetation. Reports of a 
similar nature continued and, in 1965, it was decided to initiate cropping of these three species in the South Reserve on an experimental basis. The Kakumbi Cropping Station was built outside the South Reserve opposite Mfuwe and opened that year, the cropping taking place to the north and west of Mfuwe. In 1966 and 1967, a team from the Food and Agricultural Organisation of the United Nations recommended the continuation of cropping, stating that only an immediate capital reduction of elephant, buffalo and hippo could forestall a possible disaster and loss of animals (Dodds \& Patton, 1968).

In 1968, a request was made by the Department of Game and Fisheries in Zambia to the National Council of Scientific Research to supply a physiologist to examine the reproductive state of the elephant population. The author began work that year on a study of all aspects of reproduction relevant to the population dynamics of the species.

\section{MATERIALS AND METHODS}

This study is based on 1236 elephant shot over the period from 1965 to 1969 . Material collected before 1968 was made available to the author on arrival. All elephant were shot in the South Game Reserve in the dry months of the year from May or June until early November. Incomplete, or occasionally complete, family units were shot up to and including the first part of the 1968 cropping season, and from then on whole family units were collected. Bachelor groups were avoided. The majority of the elephants were shot in the brain with a heavy calibre rifle and bled out immediately by cutting the throat with a spear. Some were killed by darting them with an overdose of succinylcholine chloride. The hunting party usually shot the first family unit found, but in some cases it was necessary to kill only the smaller sized groups. Fears have been expressed that this biased sampling would influence results. However, as there is now a considerable amount of evidence to show that these larger groups are simply an aggregation of two or more smaller family units (Laws, 1969), this method of sampling can be considered to give a representative cross-section of the female population, and of males of up to about 16 years of age.

All elephant were sent to the Kakumbi Abattoir after the hunter had noted the lactational status of the cows and the presence or absence of secretion from the temporal gland of all members of the units. The interval from exsanguination in the field to the opening of the abdominal cavity in the abattoir varied from 3 to $20 \mathrm{hr}$ and, as a consequence, certain tissues underwent autolysis and were of limited value for detailed histological examinations. At the abattoir, total body weights and shoulder heights were recorded (Hanks, 1969a). Lower jaws were removed and numbered with a metal punch for subsequent assessment of age using the method of Laws (1966). The ovaries and embryos or fetuses were collected from cows and the uterus was examined for placental scars in nonpregnant animals. The mean calving interval was estimated from the agespecific incidence of placental scars, as described by Laws (1967). The age of fetuses was determined by the method of Huggett \& Widdas (1951), using the data of Perry (1953). Ovaries were weighed to the nearest $0.1 \mathrm{~g}$ when fresh, and measured in three planes. Following fixation in $10 \%$ formalin, the ovaries 
TABLE 1

THE SEX RATIO OF LUANGWA ELEPHANT GROPPED UP TO, AND INCLUDING, I6 YEARS OF AGE

\begin{tabular}{l|r|r|l}
\hline \multicolumn{1}{c|}{ rear } & Males & Females & Ratio \\
\hline 1967 & 48 & 59 & $1: 1 \cdot 22$ \\
1968 & 93 & 108 & $1: 1 \cdot 16$ \\
1969 & 129 & 129 & $1: 1 \cdot 0$ \\
Combined & 270 & 296 & $1: 1.09$ \\
\hline
\end{tabular}

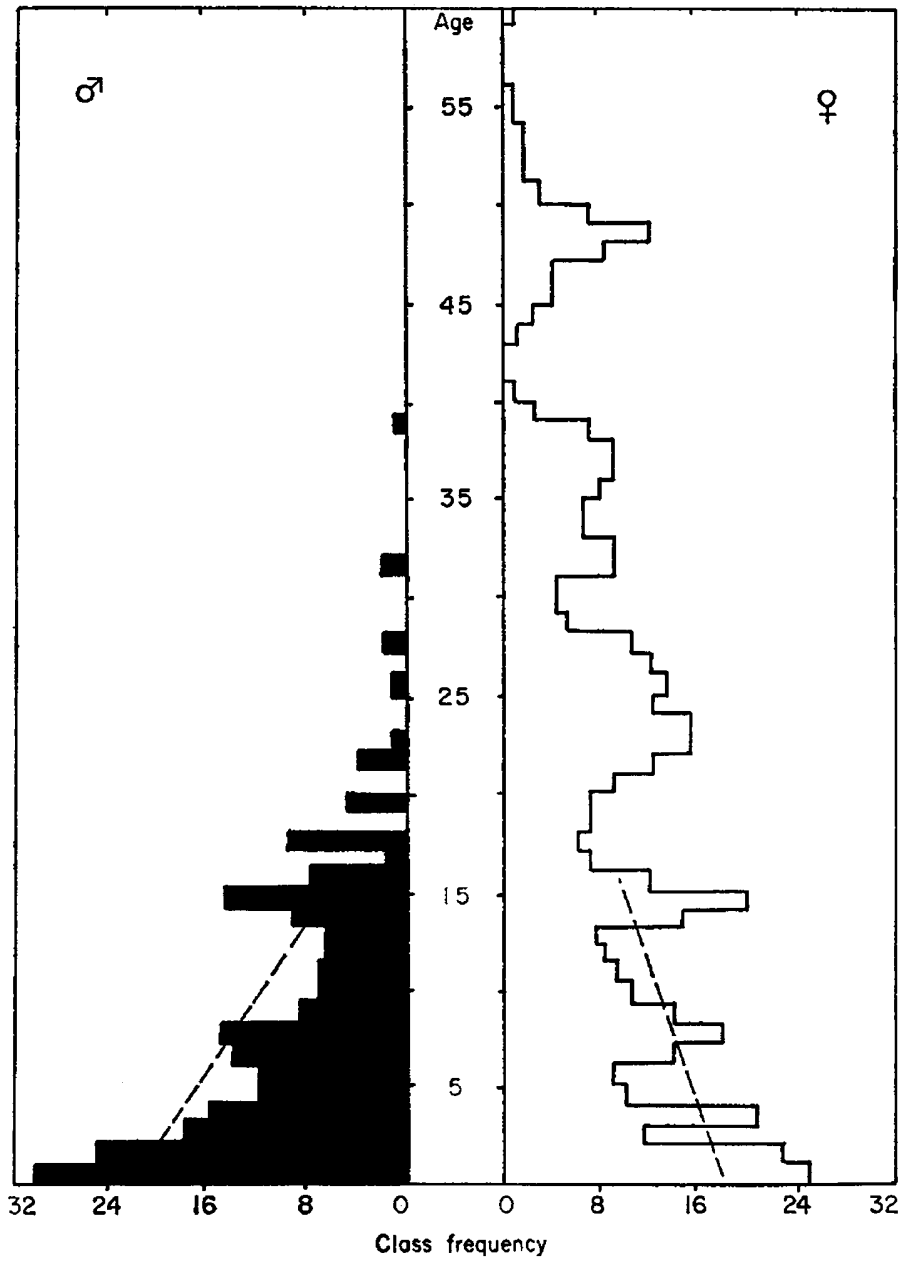

Text-pIG. 2. Year class frequencies in the Luangwa Valley elephant, complete family units shot in 1968 and 1969. 
were examined macroscopically by slicing them longitudinally at about $3-\mathrm{mm}$ intervals. All visible follicles were counted and the mean diameter measured if it was in excess of $5 \mathrm{~mm}$. Corpora lutea and corpora albicantia (nigra) were counted and the mean diameters determined for each one. Females were classified as 'immature' if their ovaries contained neither corpora lutea nor corpora albicantia, and 'mature' if at least one corpus luteum or corpus albicans was present. Luteal tissue weight was estimated using the equation of Laws (1969). In bulls, the testes and accessory organs of reproduction were weighed when fresh, and then fixed in $10 \%$ formalin for subsequent histological examination. For the purposes of this study, bull elephants have been classified as 'immature' if the testis showed no histological signs of spermatogenesis and 'mature' after the commencement of spermatogenesis.

\section{RESULTS}

\section{Sex ratio and age structure}

It was not possible to determine the sex ratio of the overall adult population as the bachelor herds were not sampled. Thus, only elephant up to, and including, the age of 16 years were used to calculate the sex ratio (Table 1) as soon after that age, bulls leave family units and become part of bachelor groups. The overall proportion of males was 0.477 , with a $95 \%$ confidence interval of \pm 0.039 . Thus, the sex ratio did not depart significantly from equality. Of the seventy-five fetuses sexed in 1969, thirty-seven were males and thirty-eight females. The total numbers of males and females of all ages shot in 1968 and 1969 are represented in Text-fig. 2, which clearly shows the absence of adult males from the family units. To determine the possibility of a differential survival of the sexes up to 16 years, regression lines were calculated for this period for males and females, but the difference was not significant $(P \bumpeq 0.40)$.

\section{Seasonal breeding}

In the Luangwa Valley from 1964 to $1968,88 \%$ of all the conceptions recorded were in the 6 months from November to April when $96 \%$ of the rain fell (Textfig. 3). In 1969, there was a shift in the peak of conceptions to June, in the dry season.

\section{Attainment of sexual maturity}

The mean age of first ovulation in elephant shot from 1967 to 1969 was about 14 years (Text-fig. 4). The mean age of the start of spermatogenesis was about 15 years (Text-figs. 5 and 6) or when the combined weights of the testes reached 650 to $700 \mathrm{~g}$, and the mean seminiferous tubule diameter reached 90 to $120 \mu \mathrm{m}$.

\section{Mean calving interval}

Ninety-eight non-pregnant mature females were examined and the frequency of placental scars were plotted against age (Text-fig. 7). The regression of the number of scars ( $s$ ) on age $(t)$ is given by:

$$
\mathrm{t}=3 \cdot 55 \mathrm{~s}+20 \cdot 1
$$


The slope of the line is an estimate of the mean calving interval, which in this case is 3.35 years. Taking the duration of pregnancy as 22 months, the length of lactational anoestrus, $x$, can be estimated as follows:

$$
\frac{\text { No. pregnant }}{\text { No. not pregnant }}=\frac{164}{147} \frac{22}{\mathrm{x}}
$$

Hence $x=20$ months. This would give a mean calving interval of about 3.5

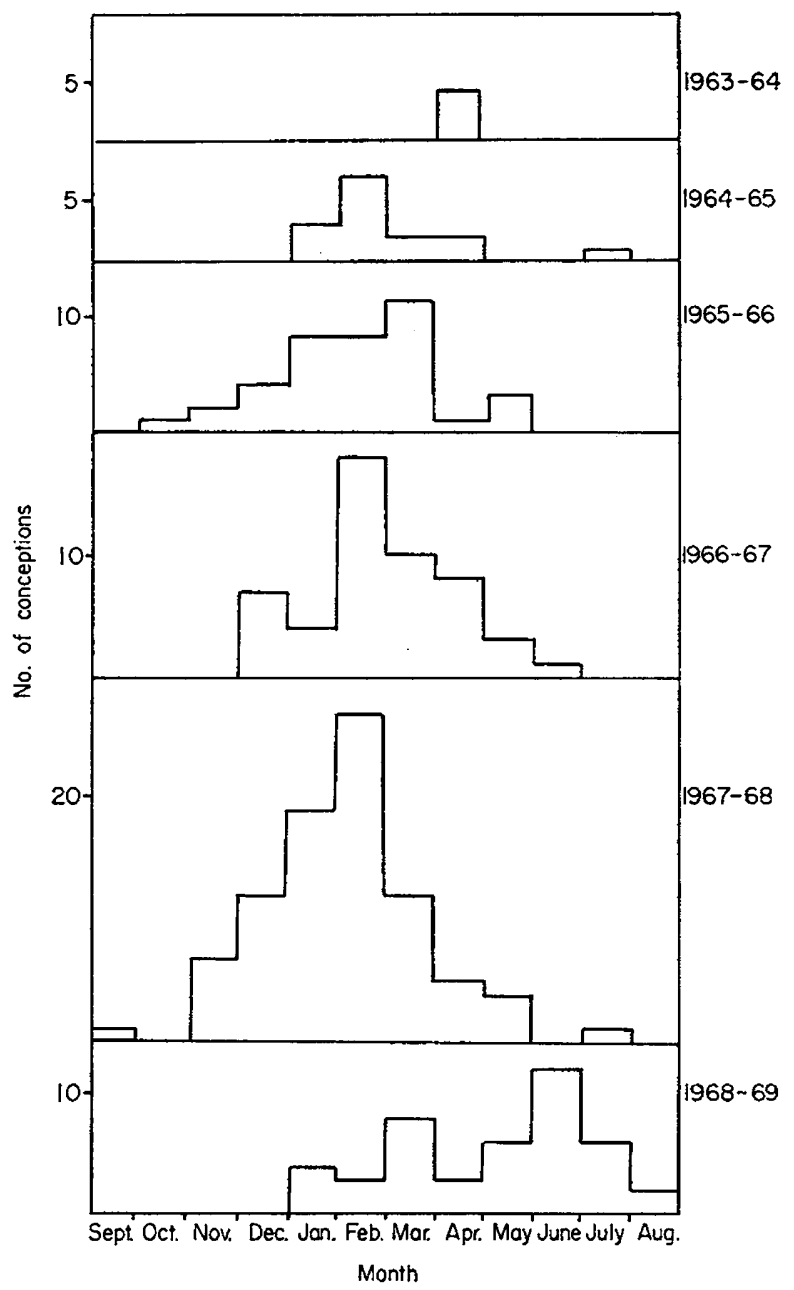

TexT-FIG. 3. Monthly frequency of elephant conceptions in the Luangwa Valley from $1963-64$ to $1968-69$.

years, agreeing closely with the figure calculated from the incidence of placental scars.

\section{Recruitment}

In the whole-family units that were killed, 474 were females and fifty-seven were calves of both sexes less than 1 year old. Assuming the overall sex ratio 


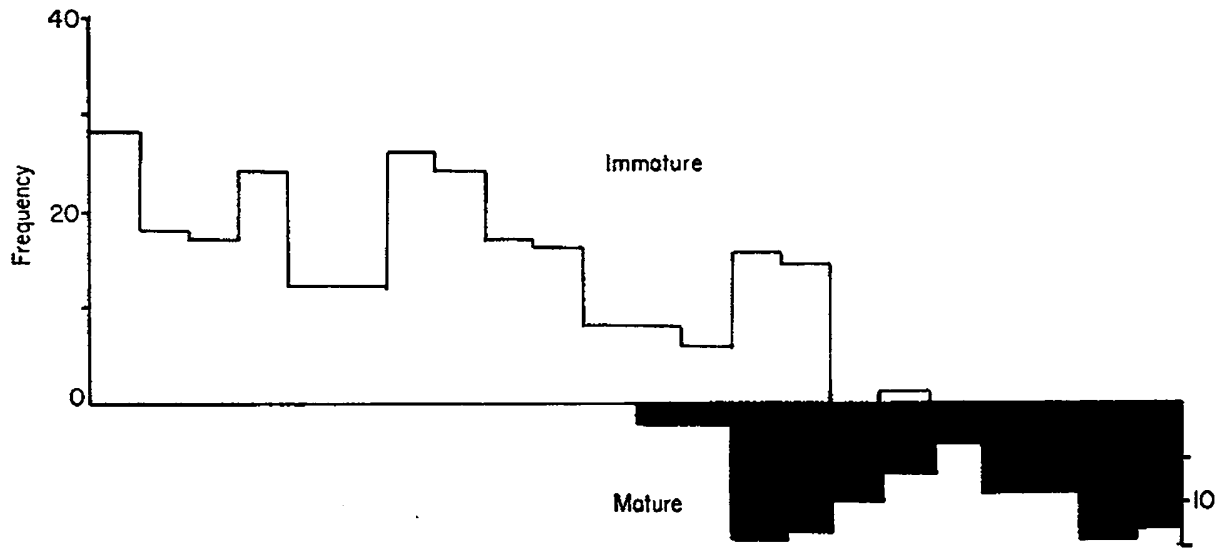

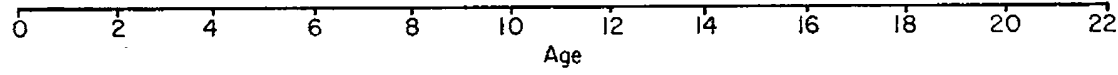

TEXT-FIG. 4. Year class frequencies of immature (above line) and mature (below line) female elephants examined in the Luangwa Valley from 1967 to 1969.

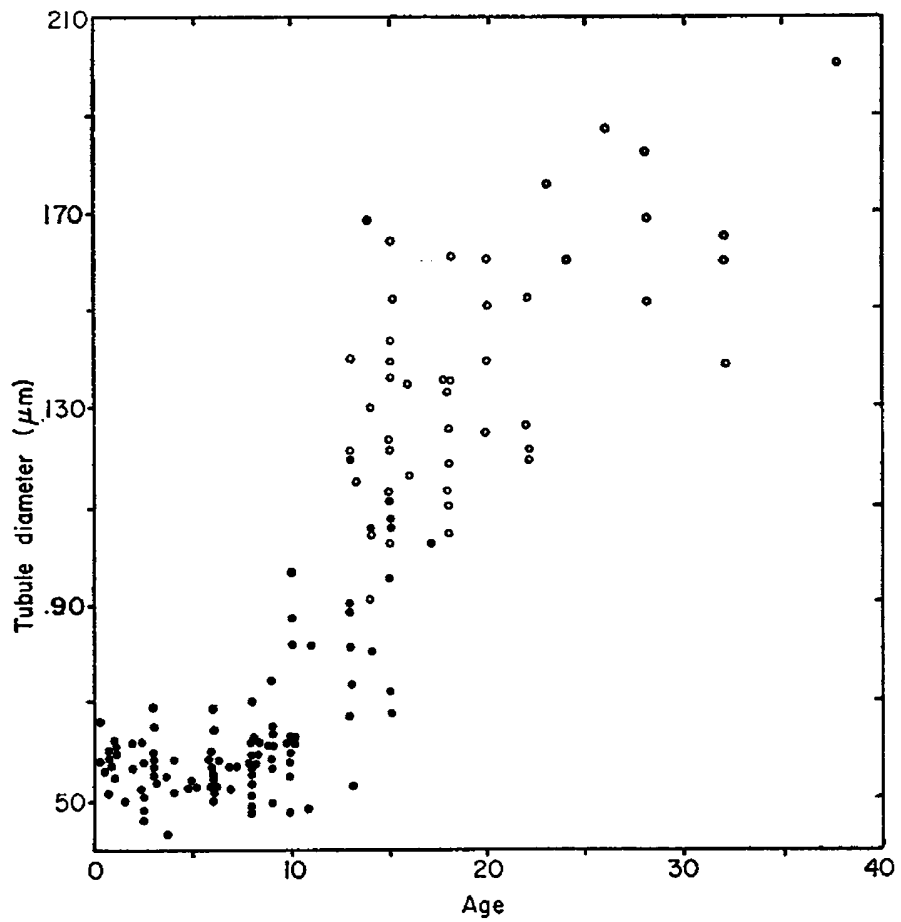

TeXr-pIG. 5. Variations in seminiferous tubule diameter with age. Closed circles-no spermatogenesis; open circles-at least some through to full spermatogenesis. 
of the population as a whole to be equal, the percentage of calves less than 1 year old was therefore $6 \%$. The age structure of the elephant family units is shown smoothed in Text-fig. 8 as 3-year running averages, base year 1969, and

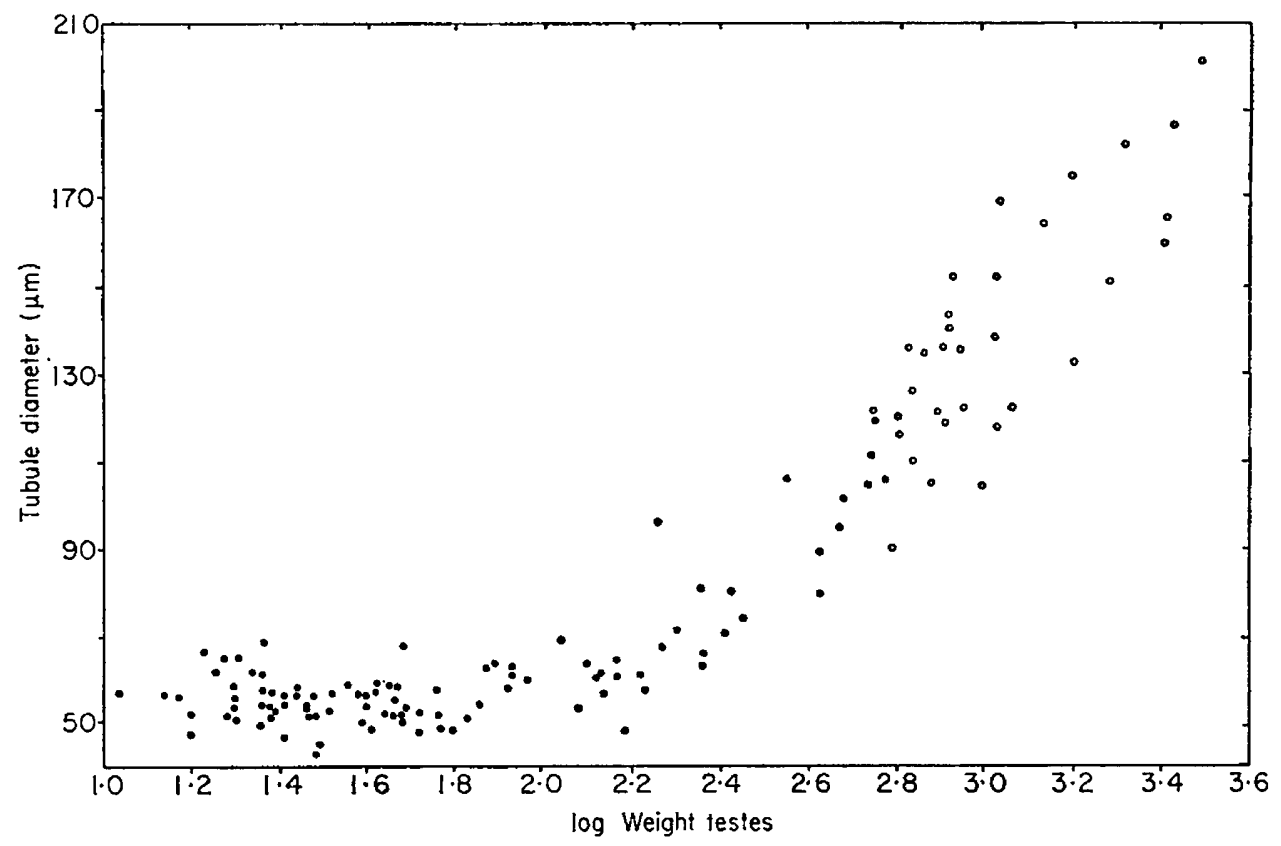

TEXr-Fig. 6. Variations in seminiferous tubule diameter with $\log$ combined weights of testes. Closed circles-no spermatogenesis; open circles-at least some through to full spermatogenesis.

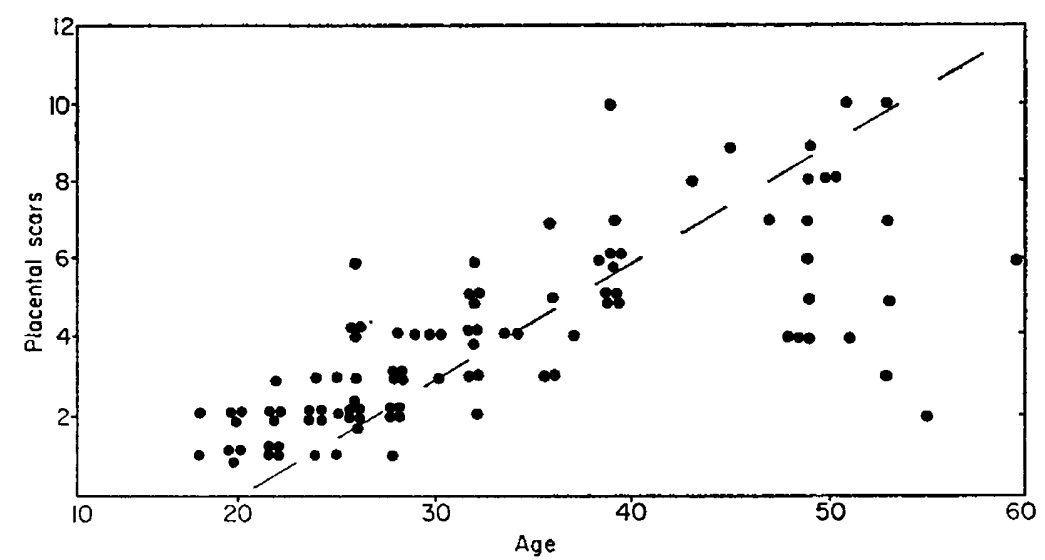

TExT-FIG. 7. Relation between number of placental scars and age in years. The regression of the number of scars (s) on age $(t)$ is given by: $t=3 \cdot 35 s+20 \cdot 1$.

this seems to indicate cycles of increased recruitment during certain years, very similar to the Murchison Falls Park North elephant population in East Africa (Laws, 1969), but apparently unrelated to rainfall. 
Reproduction and age

Variation in the $\mathrm{m}_{\mathrm{x}}$ value (the mean number of female offspring born/female/ year) is shown in Table 2, which indicates a peak of fertility in the 18- to 19year-old elephant, and a reduction from about 40 years. Macroscopic follicles

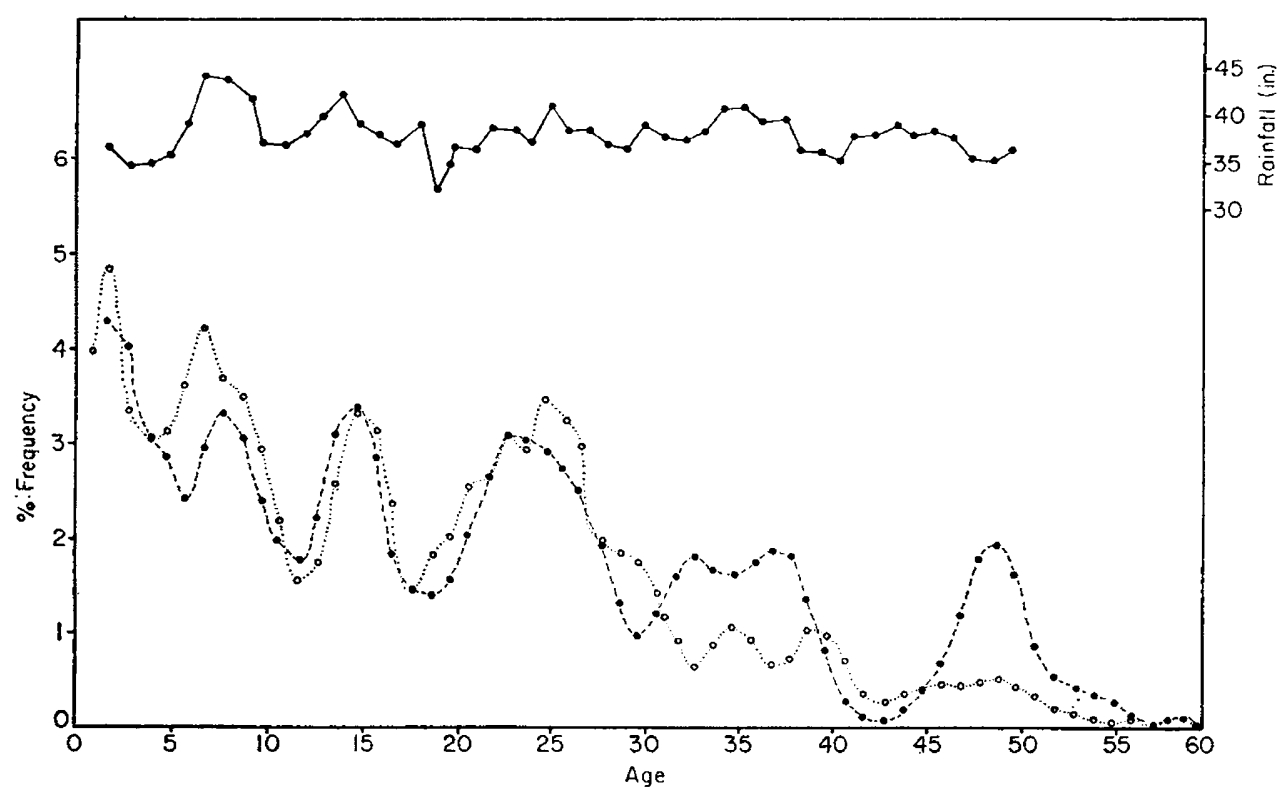

Text-pig. 8. Age structure of the Luangwa Valley elephant family units smoothed as 3-year running averages, base year $1969(\bullet--\bullet)$, compared with the Murchison Falls Park North elephants, sexes combined, base year $1966(0---0)$, as described by Laws (1969). The rainfall records (—_- ) are the 3-year running averages for the Luangwa Basin, correlated with the 1969 base year.

TABLE 2

VARIATIONS IN $m_{x}$ VALUES WITH AGE FOR 499 FEMALE LUANGWA ELEPHANTS EXAMINED FROM 1967 TO 1969

\begin{tabular}{l|c|c|c|c|c|c}
\hline $\begin{array}{c}\text { Age } \\
\text { (years) }\end{array}$ & $\begin{array}{c}\text { No. } \\
\text { classified }\end{array}$ & $\begin{array}{c}\text { No. } \\
\text { pregnant }\end{array}$ & $\%$ & $\mathrm{~m}_{\mathrm{x}}$ & $\begin{array}{c}\text { No. not } \\
\text { pregnant or } \\
\text { lactating } \\
\text { (mature females } \\
\text { only) }\end{array}$ & $\%$ \\
\hline 11 to 12 & 8 & 0 & 0 & 0 & 0 & 0 \\
13 to 14 & 29 & 3 & $10 \cdot 3$ & $0 \cdot 025$ & 0 & 0 \\
15 to 17 & 51 & 22 & $43 \cdot 1$ & $0 \cdot 107$ & 0 & 0 \\
18 to 19 & 25 & 19 & $76 \cdot 0$ & $0 \cdot 190$ & 0 & 0 \\
20 to 29 & 172 & 87 & $50 \cdot 6$ & $0 \cdot 126$ & 0 & 0 \\
30 to 39 & 120 & 60 & $50 \cdot 0$ & $0 \cdot 125$ & 1 & $0 \cdot 8$ \\
40 to 49 & 64 & 27 & $42 \cdot 1$ & $0 \cdot 105$ & 4 & $6 \cdot 2$ \\
50 to 60 & 30 & 10 & $33 \cdot 3$ & $0 \cdot 083$ & 5 & $16 \cdot 6$ \\
\hline
\end{tabular}

were found in all but one of the five oldest female elephants killed (Table 3). The relationship between corpora albicantia number and age is shown in Text-fig. 9. There was considerable scatter, but an increase with age, the 
maximum number (seventy-three) being recorded in a 39-year-old female. A line of 'best-fit' calculated by Bartlett's method gave:

$$
\mathrm{y}=0 \cdot 62 \mathrm{x}-2 \cdot 88
$$

which indicated an average increase of about $0 \cdot 6$ corpora albicantia a year.

TABLE 3

OVARIAN MORPHOLOGY AND LACTATION OF FIVE LUANGWA ELEPHANTS

\begin{tabular}{c|c|c|c|c|c}
\hline $\begin{array}{c}\text { Elephant } \\
\text { no. }\end{array}$ & Age & $\begin{array}{c}\text { Corpora } \\
\text { lutea }\end{array}$ & $\begin{array}{c}\text { Corpora } \\
\text { nigra }\end{array}$ & $\begin{array}{c}\text { Macroscopic } \\
\text { follicles }\end{array}$ & Lactating \\
\hline 1 & 55 & 0 & 24 & 280 & Yes \\
2 & 55 & $6 \dagger$ & 14 & 3 & Yes \\
3 & 57 & 0 & 37 & 25 & No \\
4 & 57 & $2^{*}$ & 30 & 1 & Yes \\
5 & 60 & 0 & 34 & 0 & No \\
\hline
\end{tabular}

* Diameter of corpora lutea $1 \times 6 \mathrm{~mm}, 1 \times 4 \mathrm{~mm}$. $\uparrow$ Pregnant. 17-month fetus.

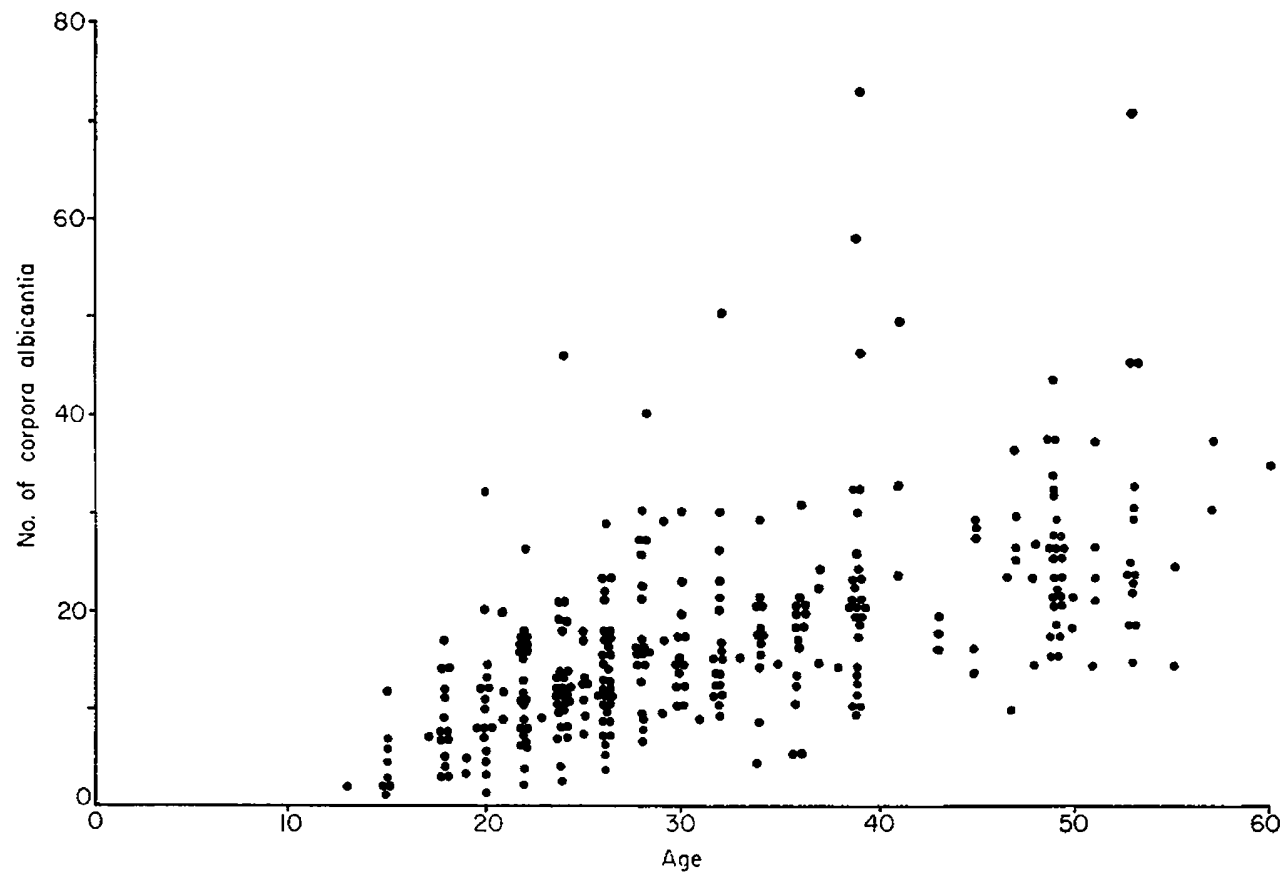

TexT-Fig. 9. Relationship between corpora albicantia number and age in the Luangwa Valley elephant.

\section{DISCUSSION}

The change in the season of breeding in 1969 was unexpected since, in previous years, the majority of conceptions were closely correlated with the rainy season (Hanks, 1969b). It was suggested that a change in the elephant's diet 
from browse and dry grass, with its low protein content at the end of the dry season, to a diet of fresh green grass with a high protein content (Table 4) at the height of the rains, stimulated ovulation and fertile mating. This is belied, however, by the situation in 1969, when the rainfall pattern in the Valley itself was similar to preceding years, and yet the peak of conceptions was well after the height of the rains. This suggests that either the proximate factors (Baker, 1938) influencing the time of conception of elephant are more complicated than variations in the plane of nutritrition, or a different elephant population had moved into the area from outside.

TABLE 4

GRUDE PROTEIN CONTENT FOR NATURAL GRASSLAND AT MAZABUKA UNDER REPEATED MOWING

\begin{tabular}{l|c||l|l||l|l}
\hline Month & $\begin{array}{c}\text { Crude protein } \\
(\%)\end{array}$ & Month & $\begin{array}{c}\text { Crude protein } \\
(\%)\end{array}$ & Month & $\begin{array}{c}\text { Crude protein } \\
(\%)\end{array}$ \\
\cline { 2 - 5 } & 3.35 & March & $4 \cdot 6$ & July & $1 \cdot 08$ \\
November & $11 \cdot 01$ & April & $4 \cdot 3$ & August & 0.86 \\
December & $6 \cdot 13$ & May & $2 \cdot 2$ & September & 0.68 \\
January & $5 \cdot 15$ & June & $2 \cdot 1$ & October & 0.64 \\
\hline
\end{tabular}

(From Darling (1960) quoting from an FAO grassland mission to N. Rhodesia (Zambia)).

On the basis of variations in the mean seminiferous tubule diameters, Laws (1969) suggested that the male elephant has a seasonal cycle. Data from Zambian males (Text-figs. 5 and 6 ) show how tubule diameters increase with age and testis weight, so that any small change in mean diameter is likely to be masked by the age distribution of the sample. Short, Mann \& Hay (1967) found elephant testicular testosterone concentrations ranging from 3 to $490 \mu \mathrm{g} / 100 \mathrm{~g}$ testis, and such an extreme range in concentrations might suggest some seasonal variation. However, these values were apparently unrelated to season, age or behavioural status. Therefore, there appears to be no positive proof of cyclical reproductive activity in the male African elephant.

Sadleir (1969) has reviewed the effects of nutrition on the attainment of puberty in wild mammals. Clearly, the level of nutrition plays a prominent part in determining the age of puberty in the few groups of mammals so far studied. The Luangwa Valley elephant show a mean age of first ovulation of about 14 years, which is very similar to the Murchison Falls Park North elephant population described by Laws \& Parker (1968).

The seasonal breeding of the elephant in Zambia, and the limitation of the cropping to the dry months of the year, have been of great use in confirming calculations of the calving intervals. Up to and including 1968, nearly all the conceptions took place in the rains. With a 22 -month gestation period, parturition would thus occur in the early half of the rainy season 2 years later. In Text-fig. 10, a theoretical diagram of three different possible elephant calving intervals is shown. Cropping took place only in the dry season (with a 3-year calving interval, in any dry season, with an even distribution of years of conceptions, $66 \%$ of the adult postpubertal elephant sampled would be pregnant; 
with a 4-year calving interval, $50 \%$ would be pregnant, etc.). In the Luangwa Valley, approximately $50 \%$ of the adult postpubertal elephant were pregnant in 1967 and 1968. In both years, there was an even distribution of pregnancies. This indicated a mean 4-year calving interval. This calculation was somewhat complicated in 1969 by the shift in the breeding season but, making allowances for those elephant which had corpora lutea but no visible embryos, there was a $56 \%$ pregnancy rate. These observations indicate that the mean calving interval is between 3.5 and 4 years.

As there is some doubt about the permanence of placental scars over long

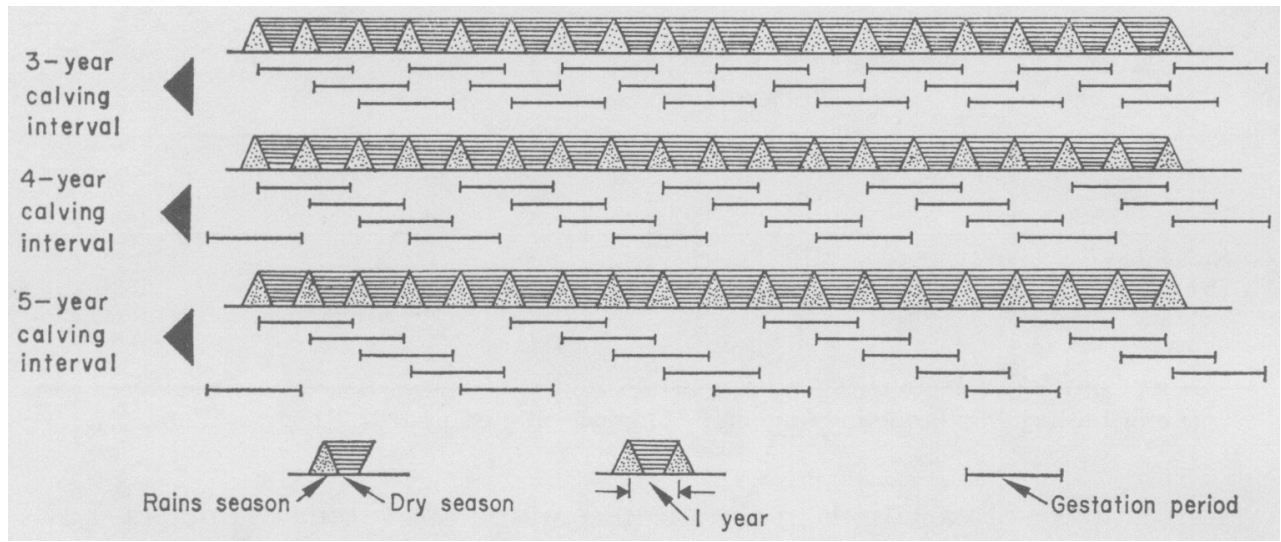

TEXT-FIG. 10. Theoretical diagram of three different possible elephant calving intervals (for explanation, see text).

periods of time (Laws, 1967), certain anomalous females in Text-fig. 7 can be eliminated and the regression recalculated. This gives:

$$
\mathrm{t}=3 \cdot 39 \mathrm{~s}+18 \cdot 3 \text {. }
$$

The $95 \%$ confidence intervals for the slope are \pm 0.38 , giving a calving interval within the range 3.00 to 3.75 years.

Laws (1969) presented material indicating that recruitment and early mortality in elephants are significantly influenced by climatic changes, and he suggested that the cycles of recruitment were of much greater magnitude than those claimed by Buss \& Savidge (1966). The major and pronounced 'troughs' and 'peaks' in Zambia seem very similar to those in the Murchison Falls Park North elephant population (Laws, 1969), and yet the base year for Zambia was 1969 and for East Africa was 1966 (Text-fig. 8). As it is extremely unlikely that the elephants in Zambia would experience cycles of recruitment exactly 3 years out of phase with elephants in East Africa and of very similar wave-length and amplitude, it must be concluded that the 'cycles of recruitment' are artefacts caused by slight inaccuracies in the ageing technique of Laws (1966). Sikes (1968) was cautious in assigning ages to her elephant, and in comparing her technique with that of Laws, she observed that 'the ages arbitrarily assigned by Laws (1966) to various stages in the molar progression are indicated in the right margin of the chart, but it will be observed that they contain several 
very irregular increments and other anomalies'. These irregular increments would be sufficient to produce the artefact of apparent cycles of recruitment.

Perry (1953) noted that it could not be shown that any in his sample of eighty-one female elephant killed in Uganda had ceased to breed. Laws, Parker \& Johnstone (1970) recorded that all the females in the 56- to 60-yearold group in Murchison Falls Park South were reproductively inactive, and they likened this decline in activity to the human menopause. Adams (1970) noted

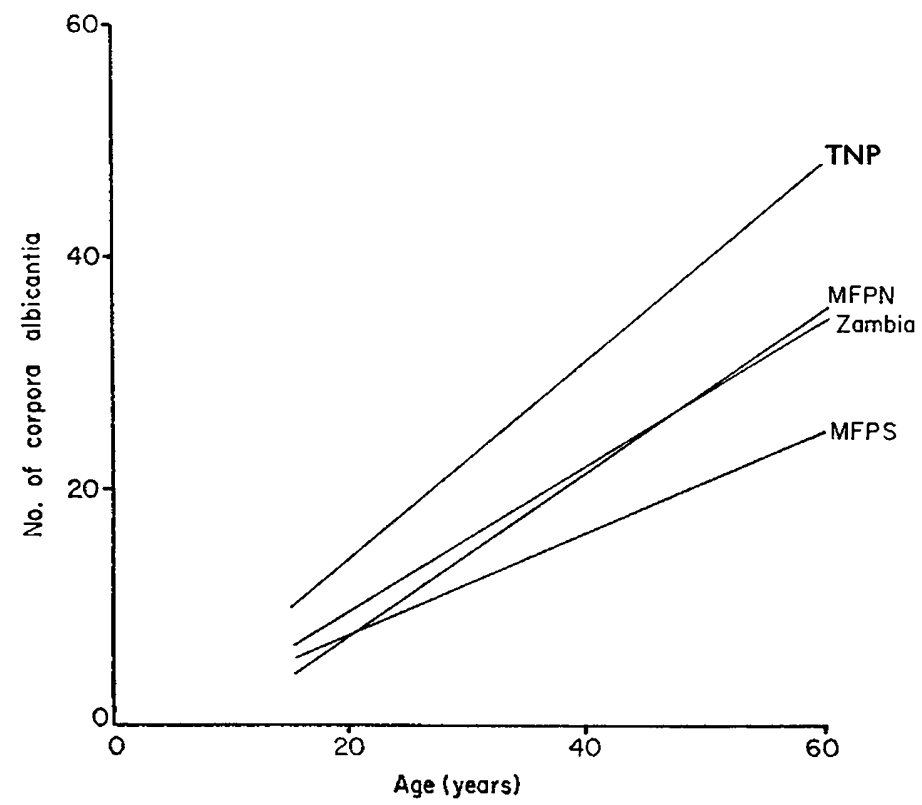

Text-Fig. 11. A comparison of the regression of corpora albicantia on age (for explanation, see text). TNP $=$ Tsavo National Park; MFPN = Murchison Falls Park North; MFPS = Murchison Falls Park South.

that in laboratory animals defects in the uterus are mainly responsible for the decline in fertility associated with advancing age. Apart from specific changes in the endometrium, e.g. cystic glandular hyperplasia, which has been reported in the rabbit, and which occurs in the elephant in Zambia, the nature of the uterine defects is obscure. In man, menopause imposes an absolute limit to the reproductive capacity when there are no more oocytes available for ovulation (Jones, 1970). Only one of the five very old elephant examined in Zambia (Table 3) appeared to have no follicles left in its ovaries. Perhaps, in the elephant, reproductive senescence may be a combination of uterine defects and a reduction of oocyte number.

Laws (1969) noted an increase in the number of corpora albicantia with age in three elephant populations in East Africa and he assumed that those animals with the largest number of corpora albicantia were the most fertile. However, it seems more likely that there is, in fact, a negative correlation between corpora albicantia number and fertility, since a 27 -year-old elephant that died in a zoo, never having been mated, had over fifty corpora albicantia (Short, 1969). The 
regression of corpora albicantia with age in Zambia is similar to the situation in the Murchison Falls Park North elephant population in Uganda (Text-fig. 11), but from this evidence alone one cannot make comparisons about the relative fertility of the two populations.

\section{ACKNOWLEDGMENTS}

The assistance and co-operation of Dr P. Albl, Mr J. Botha, Mr D. H. Hale, and Mr R. Langeveld at the Kakumbi Abattoir is gratefully acknowledged. $\mathrm{Mr}$ A. A. Phiri assisted with most of the ageing and measuring of elephant, and with the histological preparations. The UN/FAO Luangwa Valley Conservation and Development Project provided facilities at Kakumbi and Chipata. The completion of this study in Cambridge was made possible by a grant from the World Wildlife Fund, and my thanks are due to Dr R. V. Short of Cambridge University for help and encouragement throughout this project.

\section{REFERENCES}

ADAMs, C. E. (1970) Ageing and reproduction in the female mammal with particular reference to the rabbit. J. Reprod. Fert., Suppl. 12, 1.

Ansell, W. F. H. (1960) Mammals of Northern Rhodesia. Government Printer, Lusaka.

AstLe, W. L., WeBster, R. \& LAWRENCE, G. J. (1969) Land classification for management planning in the Luangwa Valley of Zambia. Fnl appl. Ecol. 6, 143.

BAKER, J. R. (1938) Evolution in breeding seasons. In: Evolution Essays on Aspects of Evolutionary Biology. Presented to Professor E. S. Goodrich. Ed. G. R. deBear. Clarendon Press, Oxford.

Buss, I. O. \& SAVIDGE, J. M. (1966) Change in population number and reproduction rates of elephants in Uganda. F. Wildl. Mgmt, 30, 791.

Darling, F. F. (1960) Wildlife in an African territory. Oxford University Press, London.

Department of Game and Tsetse Control (1947) Annual Report. Government Printer, Lusaka.

Dodds, D. G. \& Patton, D. R. (1968) Wildlife and land-use survey of the Luangwa Valley. FAO, Rome.

Hanks, J. (1969a) Growth in weight of the female African elephant in Zambia. E. Afr. Wildl. Fnl, 7, 7.

HaNks, J. (1969b) Seasonal breeding of the African elephant in Zambia. E. Afr. Wildl. Fnl, 7, 167.

Huggetr, A. St.G. \& Wrddas, W. F. (1951) The relationship between mammalian foetal weight and conception age. 7. Physiol., Lond. 114, 306.

Jones, E. G. (1970) The ageing ovary and its influence on reproductive capacity. F. Reprod. Fert., Suppl. 12, 17.

LAws, R. M. (1966) Age criteria for the African elephant, Loxodonta a. africana. E. Afr. Wildl. Fnl,4,1.

LAws, R. M. (1967) Occurrence of placental scars in the uterus of the African elephant (Loxodonta africana). 7. Reprod. Fert. 14, 445.

LAws, R. M. (1969) Aspects of reproduction in the African elephant, Loxodonta africana. F. Reprod. Fert., Suppl. 6, 193.

LAws, R. M. \& Parker, I. S. C. (1968) Recent studies on elephant populations in East Africa. Symp. zool. Soc. Lond. 21, 319.

Laws, R. M., PARker, I. S. C. \& Johnstone, R. C. B. (1970) Elephants and habitats in North Bunyoro, Uganda. E. Afr. Wildl. $7 n l, 8,163$.

Perry, J. S. (1953) The reproduction of the African elephant, Loxodonta africana. Phil. Trans. R. Soc. B, 237, 93.

SADLEIR, R. M. F. S. (1969) The ecology of reproduction in wild and domestic animals. Methuen, London.

SHORT, R. V. (1969) Notes on the teeth and ovaries of an African elephant (Loxodonta africana) of known age. F. Zool., Lond. 158, 421.

Short, R. V., MANN, T. \& HAy, M. F. (1967) Male reproductive organs of the African elephant, Loxodonta africana. F. Reprod. Fert. 13, 517.

Sikes, S. K. (1968) The African elephant, Loxodonta africana: a field method for the estimation of age. 7. Zool., Lond. 154, 235. 